\title{
Gender Pedagogy in Swedish Pre-Schools: An Overview
}

\author{
Emma Bayne
}

(C) The Author(s) 2009. This article is published with open access at Springerlink.com

\begin{abstract}
Sweden is often hailed as a pioneering country regarding gender equity, but it still has gender equity issues to deal with, and gender stereotyping is sometimes mentioned as one of them. Since the 1990s, Sweden has seen the emergence of many gender pedagogy projects, not least in pre-schools. With gender equity projects among adults yielding limited results, the focus has shifted to children to see if gender stereotypes can be countered in childhood. This article aims to provide an overview of the gender pedagogy projects that have been carried out in Swedish pre-schools. The article covers background, methods and insights gained.
\end{abstract}

Keywords Education - Countering gender stereotypes - Gender pedagogy · Pre-schools · Sweden · Swedish

\section{Standpoint on Gender and Education in Sweden}

The current approach to gender and education in Sweden goes back to the early 1960s. It was then that the gender role concept was introduced, and with it the idea that the division of labor and power was not biologically predestined but socially constructed ([40], 42, [47], 257). Gender discussions in the 1960s and 1970s focused mostly on widening traditional female and male gender roles into an holistic human role ([40], 42), as explained by Scheu [39] who suggested that traditional gender roles are mainly the result of socialisation in infancy and childhood. It is this aim towards widened gender roles for both girls and boys that still permeates the Swedish gender equity policy, although the impetus is not as strong today as it was in the 1960s and 1970s ([40], 42).

\footnotetext{
E. Bayne ( ()

Umea University, Umea, Sweden

e-mail: emma.bayne@telia.com
} 
With the establishment of the 9-year comprehensive school (in Swedish, grundskolan) in 1962 came a new curriculum, and this curriculum was the first step towards gender equity [7]. One of the objectives of the second curriculum of the 9year comprehensive school, issued in 1969, was to change stereotypic gender roles ([50], 17).

Prior to January 1, 1998, pre-schools were the responsibility of the Ministry of Health and Social Affairs. When pre-schools became the responsibility of the Ministry of Education and Research, a comprehensive curriculum for pre-schools was developed and made public for the first time. One of the clearly stated objectives of this curriculum was to counter gender stereotypes ([45], 4):

The ways in which adults respond to girls and boys, as well as the demands and expectations imposed on them [girls and boys] contribute to the shaping of girls' and boys' understanding of what is feminine and masculine. Pre-schools should work to counteract traditional gender and gender roles. Girls and boys in pre-schools should have the same opportunities to try and develop their abilities and interests without being limited by stereotyped gender roles. (page 4 My translation.)

\section{Documented Gender Stereotyping in Educational Settings}

Gender differences in school settings have been extensively documented in the last few decades. (See for example [6, 32, 34, 38, 49] regarding the situation in Sweden.) Research in schools (primary and secondary level) shows that boys are more unruly and boisterous ([49], 254, 256, [38], 78-80) while girls are self-deprecating and develop low self-esteem ([49], 262, [38], 85-88, 107). Boys dominate classrooms and play the leading parts in the classroom while the girls play minor parts in the classroom ([6], 119, 149, 166, [40], 16, 18, [38], 66-67, [32], 14, 21, 56). Boys talk considerably more than girls in the classroom ([6], 82), and elicit teacher attention more often than girls ([49], 233, 239, 254, [6], 178, 202, [40], 23, [38], 74, 77, [32], $14,[50], 40)$. But boys also receive more negative attention than girls in the form of criticism and disciplinary action ([49], 216, 254, [38], 12, 66). Research also shows that boys engage in offensive behavior against girls ([6], 218, [34], 19), including verbal and physical abuse ([32], 35-39, [38], 12, 88-95), while school staff rarely if ever stand up for the girls against the boys but often rather excused the boys' behavior ([38], 12, 88-95, [34], 27, 34, 38, [32], 15-16). Other recurring features include preferences among both boys and girls to engage in same-sex activities, both in the classroom and outside ([49], 233). In addition girls help each other while boys tend to compete with each other ([49], 176). Girls not only help their classmates, but also assist their teachers with various chores ([49], 235, [6], 73, 74, 78, $79,97,98,106,123,127,161,186,216,218,222,237,239,251$, [38], 37, 42, 47, 62 , [32], 17, 21). Girls are also placed among boys to make them less boisterous and get them to behave in a more acceptable way ([6], 86, [38], 37). Behavior that is consistent with one's gender role is regarded more positively than behavior that deviates from the gender norm ([49], 186, 188, [40], 13). This means for example 
that misbehavior and challenging school staff is generally regarded as more serious if carried out by girls than if carried out by boys ([49], 181, 183, [40], 13, [38], 39, 83-84, [34], 25, [32], 17). The differing expectations and teacher treatment of pupils depending on their sex is so characteristic that researchers have even spoken of a double hidden curriculum (in Swedish, dubbla dolda läroplanen [6], 77).

Moving on to pre-school settings, the findings there are quite similar to those found in schools: boys are more boisterous and physically active than girls ([37], 29-30, 35-36, [33], 53, 56), and they take up more space than girls ([37], 29-30). Boys also engage in offensive behavior, such as disturbing or teasing girls ([33], 38$39,43,52-53,56,76)$. As in school settings, boys dominate pre-school settings and play the leading parts, while girls play minor roles ([23] notes this primarily in parttime pre-school settings), ([37], 34, 61, [33], 63, 83). Girls often stay close to preschool staff ([31], 31), acting as little assistants and helping staff with various chores such as tidying up etc. ([23], 23, 48, 55, [37], 41-43, [31], 169, 170, 201). Boys initiate and elicit more attention from pre-school staff than do girls ([23] notes this primarily in part-time pre-school settings $(27,45,55,58,60,61,82)$, ([37], 28-34, [33], 80-122, [31], 148-149, 160-161, 164, 197, 200). Pre-school staff demands more of girls than of boys and are stricter and more controlling with girls than with boys ([33], 121, [31], 192-193). As in school settings, behavior that is consistent with ones gender role is regarded more positively than behavior that deviates from the gender norm ([37], 11, 37, [33], 20, 140, 142, [31], 30, 202).

Many of these findings are fairly similar in that they show a clear pattern of boys taking up more space and time, and with more of teacher time and attention being devoted to boys than girls. Girls and boys in pre-school settings are thus exposed to very different experiences in the same physical environment.

Gender stereotypes among pre-school and school children are not unique for Sweden but have also been documented elsewhere, for example in other Nordic countries [12], the UK [3] and the US [5].

\section{Introducing Gender Pedagogy Projects}

The 1990s saw the emergence of several gender pedagogy projects across Sweden, projects that aimed primarily at widening gender roles. In December 2003, the Swedish Government appointed the Delegation for Gender Equity (my translation) in pre-schools and the delegation produced two official reports: gendered preschools - the importance of gender equity and gender in the pedagogical work of pre-schools (my translation) [44] and Gender equity in pre-schools-the importance of gender equity and gender in the pedagogical work of pre-schools (my translation) [46]. During 2004, the Delegation for gender equity in pre-schools approved SKr 2.5 million (around US\$ 314,000) to be dedicated to a total of 18 projects aimed at increasing gender equity in pre-schools ([44], 24). Although actual figures are lacking, a rough estimate is that out of the 334,000 children that attend preschools around $15 \%$ have attended pre-schools that have carried out gender pedagogy projects ([44], 24). 
Projects to promote gender equity among adults in Sweden have often yielded limited results, which is one of the reasons for shifting focus increasingly towards children to see if gender stereotypes can somehow be countered in schools and preschools ([48], 5-6). This was the case with one of the most well-known of these gender pedagogy projects, the one carried out at two pre-schools in Gävle town, the Björntomten and Tittmyran pre-schools. The project also generated two books, Gender pedagogy: a thought and action provoking book for work with children and young people (my translation) by Kajsa Svaleryd (then a pedagogue in one of the pre-schools) and Girls, boys and pedagogues (my translation) by Kajsa Wahlström (then head of the pre-schools in Gävle).

Some of the projects involved the participation of pre-school staff and researchers in so-called research study circles (in Swedish, forskningscirklar). Study circles are an old tradition in Sweden and have been organised as early as the beginning of the 20th century. These study circles, involving pre-school staff, also included researchers (hence the term research study circle) to add knowledge on gender issues as well as to document the progress of the gender pedagogy projects [13].

\section{Recording Interaction on Film-Uncovering Gender Stereotypes}

One strategy used widely in gender related pre-school projects is to film pre-school staff and the children to see how they interact ([4, 31, 32], 31, [48], [1], 8, [13], 18, $21,32,56,57)$. This method was suggested as early as 1991 by Susanne Rithander in her book (75) Girls and boys in pre-schools-help teachers and rebels (my translation). Another strategy, adopted by some pre-schools, was for staff to keep diaries of every-day activities to help them reflect over their own interaction with the children ([4], 8, 39, 40, 70).

Adults (educational staff as well as parents) often believe they treat children equally, irrespective of gender ([31], 205, [42], 8, 9, [32], 29). But although the staff generally believed they were gender neutral in their interaction with the children, the footage often revealed very gender specific patterns with girls and boys being approached very differently ([42], 9). While staff used extensive verbal communication vis-à-vis the girls, the boys were faced with less verbal communication and were instead given more orders. Meanwhile, boys' needs were met more urgently than girls' needs and boys were allowed to take up more space and make themselves heard more often than girls [4, 44, 48]. The notion that boys' needs have to be met urgently is such a prominent feature that it has been given a name-boy panic (in Swedish, pojkpanik; [44], 14, [46], 60). Svaleryd [42], 18-19 notes that by always meeting boys' needs urgently, and often at the expense of girls' needs, pre-school staff (and other adults) indirectly indicate that boys have power, and that girls come second and aren't as important as boys.

Children are very responsive to all signals indicating expectations, requirements, and conditions regarding gender. Expectations surrounding gender roles is an aspect that reappears in various publications regarding either gender roles or education matters $[4,6,10,45,46]$. For example, these expectations dictate that girls should 
be pretty, caring and complaisant, while boys are expected to be mischievous, brave and strong ([4], 47, [46], 61, 64). Boys are not expected to be able to wait their turn but to require to have their needs met urgently ([10], 23), and they are expected to achieve great things without any guidance ([10], 26, 34). Svaleryd ([42], 37) illustrates this by talking of an instance when she taught physical fitness to a group of 5-year-olds and noticed that one of the boys helped a friend by offering support during an exercise. She praised the boy for being helpful, and only later on during the class did she realise the girls had been helping one another all along without her even having noticed, as she subconsciously believed girls were always naturally helpful. At a very early stage children realise what is particular for boys and girls, respectively ([31], 206, [42], 12). The development of traditionally gendered behavior is the result of an interaction process between a child and its environment (for example pre-school staff, parents and other children) where the child responds to situations that reinforces or confirms previously gendered traits ([23], 85), so that for example crying is accepted among girls but not boys while mischievous behavior or verbal opposition is less accepted among girls than boys ([37], 11).

Adults, parents and educational staff alike, are so entrenched in stereotypical gender roles they often don't even realise they treat boys and girls differently, thereby reproducing those same gender roles in the children in their care ([4], 49). Many pre-school teachers have been surprised or even shocked to find themselves approaching children in very different ways depending on the sex of the child in question when looking at footage of their own interaction with the children ([4], 29, 49, [42], 9, [48], 56, 57).

Pre-school staff in many of the gender pedagogy projects have realised they need to change their own stereotypical views of gender roles in order to make any changes in their work with the children in their care ([4], 7, 61, 65, [32], 29, [48], $201,215,[1], 20,[16], 22)$ - but also, prior to these gender pedagogy projects ([37], 83). Hence, these projects have indicated that gender awareness and a change in behavior could be necessary not only among the pre-school children, but equally so regarding the pre-school staff ([4], 7, 45, 61, 65, [32], 32, [48], 201, 215, [1], 16, [13], 28, 38, 45, 48, 49, 51, 52, 53, 54, 57, 60, 76, 78).

\section{Methods Used to Counter Gender Stereotypes}

A common method used in pre-schools have been what is referred to as compensatory pedagogy (in Swedish, kompensatorisk pedagogik) [1, 46, 48], a concept originally developed by the Danish pedagogue Anne Mette Kruse ([46], 24, [28]). Compensatory pedagogy builds on the notion that boys are traditionally raised to develop autonomy while girls are traditionally raised to develop closeness with other people. In order to give both girls and boys the opportunity to develop both autonomy and closeness with other people, children are encouraged to practise what they are least trained in otherwise, so typically boys are helped to develop closeness with other people while girls are helped to develop autonomy.

In order to facilitate compensatory pedagogy, some pre-schools have occasionally switched into single-sex activities, an approach that is sometimes criticised for 
increasing gender stereotypes ([46], 52). This strategy is ascribed to not only Anne Mette Kruse but also to the so-called Hjalli pedagogy, a method developed by the Icelandish pedagogue Margrét Pála Ólafsdóttir that involves single-sex groups. It is important to note that the end goal of gender pedagogy is not to cater for single-sex education on a permanent basis. Instead, introducing occasional single-sex activities was done in order to facilitate the encouragement of practising those skills least used by each sex ([48], 135, [46], 51). It may enable children otherwise inhibited by mixed-sex groups to dare trying activities not usually associated with their gender.

Wahlström ([48], 142-150) illustrates how letting the children eat lunch in singlesex units facilitated the practising of skills least used by boys and girls, respectively. Film footage had shown a clear pattern of girls catering to the boys needs by serving them food and handing them various things at the boys' beck and call, the call mostly consisting of a monosyllabic utterance, "öh". When organised into single-sex groups at different tables the staff focused on different things for the girls and boys: whereas the girls needed to practise a positive self-image, learning to act on their own wishes, viewing differences positively and showing a sense of humour, boys needed to practise a positive self-image and being helpful, being considerate to others, following set rules, waiting their turn and using their verbal skills ([48], 144).

Following a period of filming the interaction of the staff and children, many projects set out to plan pre-school activities and settings to encourage both girls and boys to develop those traits that were least developed in each one. Hence the term compensatory pedagogy, i.e., girls learn traits least common in girls (declaring their views and requests, being proud of themselves and their own views, helping themselves to things they want, daring to fail, daring to show anger, developing their experimenting skills) and boys learn traits least common in boys (such as cooperating, listening to others, showing respect, learning to wait their turn, verbal abilities in general, verbalising emotions), thereby compensating for what they don't already have and so widening their gender roles. Often, this meant teaching the boys to be more verbally communicative and caring, whilst encouraging girls to speak up for themselves and claim space, thereby evening out the gender gaps and widening the roles of all the children ([4], 50, [48], 138-141).

There were some concrete measures adopted in order to facilitate the gender pedagogy aim. In some places the projects involved removing some of the gender specific toys, such as dolls and cars, while focusing instead on more gender neutral items such as jigsaws and painting material [35, 42, 48]. Another strategy was to set up various play stations and have the children rotating between these stations at regular intervals in order to give everyone the chance to use the various resources at the pre-school; The footage at one particular pre-school often showed a small group of boys claiming specific items for themselves, at the expense of the other children ([48], 185-189). But like many other measures to counter gender stereotypes, the setting up of various play stations requires monitoring and follow-ups to ensure this does not return the pre-school children into old gender stereotypes albeit manifested differently.

One method suggested by [42], 121 is to invite men and women who have jobs not usually associated with their gender, such as a female pilot or a male horse carer, to visit the pre-school and talk about their work. 
Elvin-Nowak and Thomsson ([8], 247-248) suggest reading stories to children with swapped gender roles where for example the beautiful prince is saved by the brave princess, an approach practised by Davis [5].

The debate on gender in pre-schools also brought to light the fact that while boys have a name for their private parts (in Swedish, snopp), no female equivalent existed. This creates tension and taboo around female private parts, tension and taboo which do not exist for males. In 2001, Anna Kosztovics at the RFSU, the Swedish Association for Sexuality Education, launched the word snippa to denote the female private part and in 2006, the word was included in the Swedish Academy wordlist (in Swedish, Svenska akademiens ordlista) [36].

Working with gender issues sometimes went beyond the immediate pre-school setting. Stereotypical gender roles incorporate views on parents' responsibility, notably mothers' responsibility, for their children, that is to say it is often the mother who is contacted if the pre-school needs to get in touch with parents ([11], 152, [8], 242 ), thus reproducing the stereotypic view that childcare is mostly or solely the mother's responsibility. Some pre-schools therefore made a point of keeping in touch with both mothers and fathers regarding the children, in an attempt to break the pattern of just keeping in touch with the mothers ([46], 123).

\section{Insights Gained}

Kajsa Wahlström, head of the pre-schools in Gävle where gender pedagogy was developed between 1996 and 2000, says that broadening gender roles among preschool children was most difficult with those girls who had held the most subordinate roles, the most quiet girls. In order to broaden their gender roles, girls have to learn to appreciate themselves and each other. This is a much more difficult starting point than to get boys, already starting from a superior starting point, to broaden their gender roles ([48], 176-177).

Gender pedagogy projects have not received positive responses but have also been met with suspicion and resentment, both among parents and pre-school staff. Some parents show concern, and in particular much concern is focused on the welfare, sexuality and future of the boys ([32], 32, [44], 56, [1], 20, [16], 23, 27, [46], 69, 122, 161, 200, [13], 19, 32, 39, 42, 46, 50, [19], 17, 19, 25, [25]). The fact that widening gender roles for boys is much more controversial than widening gender roles for girls has to do with the male-as-norm in society which implies that whereas females may adopt male gender traits and activities and thus conform to the male norm, males cannot adopt female gender traits and activities and thus diverge from the male norm ([42], 62, [25]). In this context it is important to remember that parents are not the ones deciding whether pre-schools should work with gender issues, but rather pre-schools have an obligation to work towards gender equity, according to various laws and regulations ([46], 120, 122). These laws and regulations include the Discrimination Act [17] and the first pre-school curriculum from 1998 (in Swedish, Lpfö 98).

Wahlström ([48], 79) notes that breaking rules is something often associated with being male. Could it be that adults socialise boys into being unruly because this is 
regarded as a sign of strength and initiative ([48], 66)? A potential downside of this association of unruliness with the male gender role is that boys often receive negative feedback. Wahlström ([48], 124) poses the question whether boys receive reprimands for other people's ill-deeds as well as their own.

The work with gender issues also unveiled the fact that many children grow up in families not consisting of a heterosexual mother and father, but either in families with only one parent or with lesbian or gay parents ([46], 123). It is estimated that around 40,000 children in Sweden grow up with lesbian or gay parents ([46], 162).

It has been noted that not all municipalities are actively endorsing gender equity goals, for example by arguing that they have already achieved gender equity or that they lack time, assigning a low priority to gender equity measures in pre-schools etc., [16]. In some places, parents or staff express eagerness that their pre-school start working with gender issues, highlighting this work is still not in place everywhere ([44], 57, [46], 84). Also, a report by the Swedish National Agency for Education notes that regarding further education for pre-school teachers, gender role issues rank as the last but two out of the 19 listed areas of priority ([41], 94).

\section{Regarding the Call for More Males in Pre-Schools}

It is sometimes mentioned that more male staff in pre-schools would increase gender equity ([46], 52), a common argument being that children need male as well as female role models ([4], 24, 47). However, it has been noted by for example Rithander ([37], 87) that more men working in pre-schools will not automatically increase gender equity. Male staff will have to contribute in terms of widened gender role models rather than traditional masculinity or they will decrease, rather than increase, gender equity ([51], 22) and this source is also quoted by ([38], 113, [33], 20 and [18], 20-21, [44], 41, [16], 17, 24, 28, [46], 56).

Hence, an even distribution of female and male staff in educational settings is not an objective per se, according to the Swedish model. The objective is to eliminate gender stereotypes and widen gender roles among children.

Male pre-school staff, too, seem keen to emphasise their pedagogical skills rather than the fact that they are men when discussing their work [26, 27].

\section{The Road Ahead}

Results from all gender pedagogy projects indicate that the work of eliminating gender stereotypes has only just begun. Although much has been achieved, a lot still remains to be done, and Sweden has a long way to go if it is to eliminate gender stereotypes and allow all people to act within the full spectrum that is neither male nor female, but simply a holistic human.

However, it appears the gender pedagogy projects have had some effects, judging by an article in a Swedish newspaper [24]. There, two of the former pre-school children from the Tittmyran pre-school, now in their teens, explain some of their experiences from their pre-school years. The girl points out that girls who have 
attended the gender pedagogy pre-schools demonstrated more assertiveness than other girls, while the boy feels less prejudiced against gender untypical behavior. The gender pedagogy projects also note changes in children, such as girls being better at helping themselves to what they want ([4], 64).

Also, it seems the gender pedagogy projects have raised the awareness of gender issues in general and gender stereotypes in particular among the people participating in the projects. And with gender equity issues being a matter of awareness ([42], 33, [14], 3), this is a vital step in the right direction. Many people involved in the gender pedagogy projects have spoken of their gained knowledge in metaphorical terms, saying they have put on their gender glasses (in Swedish, genusglasögon/ jämställdhetsglasögon), meaning they see the world around them through a filter of gender awareness ([4], 35, [44], 14, [1], 16, 19, 21, 22, [46], 58, 59, 95, 130, [13], 7, 19, 20, 24, 25, 43, 64, 66, 67, 81).

Several books on gender and education have been published in recent years (see for example [2, 9, 14, 15, 20-22, 29, 30, 34, 42, 43, 48]. Also, gender pedagogy projects have attracted some media attention; A free-text search for articles containing the word "genuspedagogik" (the Swedish word for gender pedagogy) between 1996 and 2008 in the newspaper article databases Artikelsök, Mediearkivet and Presstext generates 13, 78 and 37 hits, respectively. University courses on gender and education are organised (at Stockholms University, Umeå University and Växjö University). These facts all suggest that the topic of gender pedagogy has not lost momentum since the gender pedagogy projects were evaluated in the second official report from the Delegation for gender equity in pre-schools [46].

But the second official report from the Delegation for gender equity in preschools [46] reiterates the need to proceed with gender pedagogy, maintaining the official Swedish view that gender roles are mostly the effect of socialisation processes throughout life.

One hurdle, as noted by some ([35], [46], 305-306) is that although pre-schools, however aptly they apply gender pedagogy while the children are in their care, cannot account for the gender stereotypes reproduced by other parts of society (for example family and friends, schools, media) and so may face the difficult task of implementing a gender neutral approach that may be either resisted or even opposed by much of society. The sometimes stereotypical gender roles of pre-school staff ([4], 29, 49, [42], 9, [48], 56, 57) and parents ([32], 32, [44], 56, [16], 23, 27, [46], $69,122,161,200,[19], 17,19,25)$ as well as other adults in society generates the question of how to widen children's gender roles with a sustainable result while adults remain limited in their gender roles.

And maybe this is the ultimate challenge of any gender pedagogy project: given the discovery of how adults treat boys and girls differently and also how adults have different expectations for boys and girls, and considering the fact that the development of stereotyped gender roles is shaped partly in child-adult interaction (for example between pre-school staff and children), the pre-school gender pedagogy projects seem to be faced with something of a catch 22-gender equity projects aimed at educational settings have partly come about as a result of the limited success of adult gender equity projects. But how can children be expected to 
change their stereotyped gender behavior if the adults around them cannot do the same?

Open Access This article is distributed under the terms of the Creative Commons Attribution Noncommercial License which permits any noncommercial use, distribution, and reproduction in any medium, provided the original author(s) and source are credited.

\section{References}

1. Almqvist, A., Fjellström-Åhman, M., Fors-Mattsson, K., \& Tjikkom, A. (2005). Genus/ Jämställdhetsstrategi Förskolor och skolor 2005-2008. Jokkmokks kommun: Jokkmokk.

2. Ambjörnsson, F. (2004). I en klass för sig: genus, klass och sexualitet bland gymnasietjejer. Stockholm: Ordfront.

3. Askew, S., \& Ross, C. (1993). Boys don't cry. Buckingham: Open University Press.

4. Berge, B. -M. (2001). Kunskap bryter könsmönster. Rapport från projektet Vidgade Vyer 1999-2001. Kommunförbundet and Länsstyrelsen Jämtlands Län.

5. Davis, B. (2003). Frogs and snails and feminist tales. Cresskill: Hampton Press.

6. Einarsson, J., \& Hultman, T. G. (1984). Godmorgon pojkar och flickor. Malmö: Gleerups Förlag.

7. Elgqvist-Salzman, I. (1992). Straight roads and winding tracks: Swedish educational policy from a gender equality perspective. Gender \& Education, 4(1/2), 41-56.

8. Elvin-Nowak, Y., \& Thomsson, H. (2003). Att göra kön. Stockholm: Albert Bonniers förlag.

9. Erson, E. (2006). Språk och kön i utbildningsmiljö. Stockholm: Norstedts akademiska förlag.

10. Gens, I. (2002). Frain vaggan till identitet-hur fickor blir kvinnor och pojkar blir män (2d ed.). Jönköping: Seminarium.

11. Graf, J., Helmadotter, A. -M., \& Ruben, S. (1991). Visst är det skillnad!. Stockholm: Almqvist \& Wiksell Förlag.

12. Gulbrandsen, J. (1994). Är skolan till för Karin eller Erik? translated edition (translation into Swedish from Norwegian) Lund: Studentlitteratur.

13. Härnsten, G., Alm, M., Carlsson, L., Gillberg, C., Holmstrand, L., Jansson, D., Johansson, A., Linnér, S., Lund, S., Pong, K., Sjöblom, B., \& Söderlund-Wijk, B. (2007). Inre resor-Slutrapport från projektet Jämställd förskola i Kronobergs län. Södra Smålands kommuner och landsting (SSKL).

14. Hedlin, M. (2004). Lilla genushäftet: om genus och skolans jämställdhetsmail. Kalmar: Kalmar Högskola.

15. Helén, E., \& Granholm, M. T. (2007). På genusäventyr: metodbok för drama och genus i förskolan. Stockholm: Natur och Kultur.

16. Henkel, K. (2005). Vi har inte tid-Om motstaind mot implementering av jämställdhet i förskolan. Stockholm: Stockholms Universitet.

17. Integrations- och jämställdhetsdepartementet (Ministry of Integration and Gender Equality) (2008). Diskrimineringslagen (SFS 2008:567). Available from: http://www.sweden.gov.se/sb/d/3926/a/ 118187 (Accessed 1 May 2009).

18. Jalmert, L. (1984). Den svenske mannen. Stockholm: Tidens Förlag.

19. Jansson, J., \& Thimfors, S. (2007). Föräldraperspektiv på genus- och jämställdhetsarbete i förskolan. Stockholm: Lärarhögskolan.

20. Josefson, H. (2007a). Genus: hur påverkar det dig?. Stockholm: Natur och Kultur.

21. Josefson, H. (2007b). Genus Lärarbok: hur du kan arbeta med genus. Stockholm: Natur och Kultur.

22. Kåreland, L., Lindh-Munter, A., Brink, L., Andrae, M., \& Helen, S. (2005). Modig och stark-eller ligga lagt: skönlitteratur och genus $i$ skola och förskola. Stockholm: Natur och Kultur.

23. Kärrby, G. (1987). Könsskillnader och pedagogisk miljö i förskolan. Göteborg: Institutionen för pedagogik. Göteborgs universitet. Rapport nr 2.

24. Lagerblad, A. (2007a). Ingen hjärntvätt. Svenska Dagbladet, 17 Sep.

25. Lagerblad, A. (2007b). Men tänk om han blir bög. Svenska Dagbladet, 18 Sep.

26. Lagerblad, A. (2007c). Män kan mer än att snickra. Svenska Dagbladet, 19 Sep.

27. Lagerblad, A. (2007d). Man kan vara kille på olika sätt. Svenska Dagbladet, 19 Sep.

28. Länsstyrelsen Västmanland. (2007). Kompensatorisk pedagogik. Available from: http://www.jams talldskola.se/arbeta-jamstalldhet/steg2-kompensatorisk-ped.shtml (Accessed 2 July 2008). 
29. Lundberg, J. G., Bondestam, F., Franck, O., Gårdfeldt, L., \& Höglund, A. T. (2007). Genusperspektiv i skolan: om kön, kärlek och makt. Lund: Studentlitteratur.

30. Lundgren, A. S. (2000). Tre är $i$ g: perspektiv på kropp och kön $i$ skolan. Eslöv: B. Östlings bokförlag.

31. Månsson, A. (2000). Möten som formar: Interaktionsmönster på förskola mellan pedagoger och de yngsta barnen $i$ ett genusperspektiv. Malmö: Lärarhögskolan, Institutionen för pedagogik. Doktorsavhandling: 147.

32. Myndigheten för skolutveckling (The Swedish National Agency for School Improvement) (2003). Hur är det ställt? Tack, ojämt! Stockholm, Myndigheten för skolutveckling.

33. Odelfors, B. (1998). Förskolan ur ett könsperspektiv. Lund: Studentlitteratur.

34. Öhrn, E. (2002). Könsmönster i förändring? En kunskapsöversikt om unga i skolan. Skolverket (The National Agency for Education).

35. Olsson, J., \& Vollbrecht, E. (2006). Om könsmönster på förskolan. Göteborg: Göteborgs Universitet.

36. Riksförbundet för sexuell upplysning (Swedish Association for Sexuality Education). (2007). Snippor och snoppar pa frammarsch. Available from: http://www.rfsu.se/snippor_och_snoppar_pa_ frammarsch.asp (Accessed 2 Jan 2009).

37. Rithander, S. (1991). Flickor och pojkar i förskolan-hjälpfröknar och rebeller. Stockholm: Almqvist \& Wiksell Förlag.

38. Sandquist, A. -M. (1998). Visst görs vi olika!. Stockholm: Kommentus Förlag.

39. Scheu, U. (1979). Vi föds inte till flickor, vi görs till det., translated edition (translation into Swedish from German) Stockholm: Prisma.

40. Skolverket (The Swedish national Agency for Education). (1994). Flickors och pojkars olika förutsättningar och villkor -En kunskapsöversikt om könsskillnader i skolan. Stockholm: Skolverket.

41. Skolverket (The Swedish national Agency for Education). (2004). Förskola i brytningstid-Nationell utvärdering av förskolan. Stockholm: Skolverket.

42. Svaleryd, K. (2003). Genuspedagogik: en tanke- och handlingsbok för arbete med barn och unga. Stockholm: Liber.

43. Torstensson-Ed, T. (2003). Barns livsvärld. Studentlitteratur.

44. Utbildningsdepartementet (The Swedish Ministry of Education and Research) (2004). Den könade förskolan-om betydelsen av jämställdhet och genus i förskolans pedagogiska arbete, SOU 2004:115. Available from: http://www.regeringen.se/content/1/c6/03/47/60/194bfa79.pdf (Accessed 9 Sep 2008).

45. Utbildningsdepartementet (The Swedish Ministry of Education and Research) (2006a). Läroplan för förskolan, Lpfö 98. Available from: http://www.skolverket.se/skolfs?id=572 (Accessed 1 Jan 2009).

46. Utbildningsdepartementet (The Swedish Ministry of Education and Research) (2006b). Jämställdhet $i$ förskolan—om betydelsen av jämställdhet och genus i förskolans pedagogiska arbete, SOU 2006:75. Available from: http://www.regeringen.se/sb/d/6293/a/67288 (Accessed 5 August 2008).

47. Vallberg Roth, A. -C. (2001). Läroplaner för de yngre barnen, utvecklingen från 1800-talets mitt till idag. Pedagogisk Forskning i Sverige, 6(4), 241-269.

48. Wahlström, K. (2004). Flickor, pojkar och pedagoger: jämställdhetspedagogik i praktiken (2d ed.). Stockholm: Sveriges utbildningsradio.

49. Wernersson, I. (1977). Könsdifferentiering i grundskolan. Göteborg: Acta Universitatis Gotheburgensis.

50. Wernersson, I. (2006). Genusperspektiv pa pedagogik. Stockholm: Högskoleverket (Swedish National Agency for Higher Education).

51. Wernersson, I., \& Lander, R. (1979). Män och kvinnor i barnomsorgen-en analys av könskvotering, yrkesval och arbetstrivsel. Stockholm: Jämställdhetskommittén.

\section{Author Biography}

Emma Bayne holds a Master of Fine Arts F.I.S.T.C. (Fellow of the Institute of Scientific and Technical Communicators). She is a technical author. Her current focus on gender pedagogy projects in Swedish pre-schools was initially raised during educational science studies at Umea University. 